\title{
Corn Yield Response to Reduced Water Use at Different Growth Stages
}

\author{
Hirut Kebede', Ruixiu Sui', Daniel K. Fisher' ${ }^{1}$, Krishna N. Reddy¹, Nacer Bellaloui², \\ William T. Molin 1 \\ ${ }^{1}$ Crop Production Systems Research Unit, USDA-ARS, Stoneville, MS, USA \\ ${ }^{2}$ Crop Genetics Research Unit, USDA-ARS, Stoneville, MS, USA \\ Email: hirkebede@yahoo.com
}

Received 30 September 2014; revised 29 October 2014; accepted 15 November 2014

Copyright (C) 2014 by authors and Scientific Research Publishing Inc.

This work is licensed under the Creative Commons Attribution International License (CC BY). http://creativecommons.org/licenses/by/4.0/

(c) (i) Open Access

\section{Abstract}

To develop an efficient water use strategy for crop irrigation, we need to know how much water can be reduced without decreasing yield. A study was designed to determine corn growth stages at which water could be reduced without affecting grain yield, and at what soil moisture level water deficit stress begins in the plants in a silt loam soil. An experiment was conducted in a randomized complete block with a $3 \times 4$ factorial design in four replications, where treatments consisted of three soil moisture levels [100\%, 75\%, and $50 \%$ of field capacity (FC) of a silt loam soil by weight] and four growth stages [fourteen leaf stage (V14), silking (R1), milk (R3), and dent (R5) stages] in a greenhouse. Growth stages at the reproductive and grain fill stages of corn were selected because this study was intended for the Mississippi Delta, where there is frequent drought during these growth stages making irrigation necessary for corn production, whereas there is usually adequate rainfall during the vegetative growth stages. Results from this study showed that reducing soil moisture from $100 \%$ FC (fully irrigated) to $75 \%$ FC of a silt loam soil starting at the R1 growth stage in corn did not reduce yield significantly compared to yield from the $100 \% \mathrm{FC}$, while saving a significant amount of water. Physiological investigations at the three soil moisture treatments showed that a mild moisture deficit stress might have started at the $75 \%$ FC treatment. With further investigation, if savings in water at $75 \%$ FC result in a significant reduction in energy cost, it may be profitable to reduce soil moisture to $75 \% \mathrm{FC}$ in a silt loam soil.

\section{Keywords}

Corn, Water Use, Soil Moisture, Growth Stage, Field Capacity

\section{Introduction}

Efficient use of water in agriculture has become an issue as available water resources become scarce [1] [2].

How to cite this paper: Kebede, H., Sui, R.X., Fisher, D.K., Reddy, K.N., Bellaloui, N. and Molin, W.T. (2014) Corn Yield Response to Reduced Water Use at Different Growth Stages. Agricultural Sciences, 5, 1305-1315. 
Groundwater levels have declined across much of the United States including the Mississippi Delta [3] [4]. Due to the increased cost of energy and overdraft of the Mississippi Delta Shallow Alluvial Aquifer, there is a need to use irrigation water efficiently in the region. In order to develop an efficient water use strategy in crop irrigation, we need to know how much water can be reduced without decreasing yield. This depends, among other things, on the growth stage of the plant, its rate of water use and plant available water (which depends on the soil type) involving evapotranspiration demand. Corn requires different amounts of water at different growth stages. It requires less water at the early and late growth stages, while the peak water requirement occurs during the period two weeks before and after silking [5]-[7]. In the Mississippi Delta, there is usually adequate precipitation during the vegetative growth stages of corn plants (April-May), but during the reproductive and the grain fill stages (June-August) there is frequent drought and irrigation is required to avoid yield loss. Therefore, the need for efficient use of irrigation water in corn in the Mississippi Delta arises mainly during the reproductive and the grain fill stages of corn.

Physiological responses of plants to a gradient of soil moisture content can help in determining at what soil moisture level plant water deficit stress is initiated, which then can be used to determine how much water can be reduced without affecting major physiological processes that contribute to crop growth and yield. A major effect of soil moisture reduction in plants is reduction in photosynthesis [8]-[10]. Kernel growth and development in corn is highly dependent on assimilate supply from concurrent photosynthesis, supplemented with remobilized stem carbohydrate reserves during grain fill [11] [12]. Responses of photosynthesis and photosynthetic pigments content (chlorophyll and carotenoids), chlorophyll fluorescence, relative water content and other physiological parameters are often used to determine the effects of soil moisture stress in plants [13]-[15].

Amount of soil water that is available to plants (water held in soil between field capacity and permanent wilting point) depends on the soil textural class. Silt loam soils hold the largest amount of plant available water whereas sandy soils hold the lowest amount of plant available water [16]-[18]. In this study a Dundee silt loam soil, which is one of the typical soils in the Mississippi Delta, was used and the soil moisture treatments were based on the field capacity of this soil. There is no report on efficient water use in corn at different growth stages on a specific soil type of the Mississippi Delta. Therefore, this study was designed to determine at which reproductive and grain fill stages water can be reduced without affecting corn yield, and at what soil moisture level water deficit stress begins on the plants in a Dundee silt loam soil.

\section{Materials and Methods}

\subsection{Experimental Design}

A greenhouse experiment was conducted using a commercial corn hybrid, Pioneer P33N58, in the fall of 2013. The experimental design was a randomized complete block with a $3 \times 4$ factorial design in four replications. The treatments consisted of three soil moisture levels and four growth stages of corn during late vegetative, reproductive, and grain fill stages. The three soil moisture treatments included $100 \%, 75 \%$ and $50 \%$ of field capacity (FC) of a silt loam soil by weight. The four corn growth stages included the fourteen leaf stage (V14), silking (R1), milk stage (R3) and dent stage (R5). A Dundee silt loam soil (32\% sand, 54\% silt and 14\% clay), one of the typical soil types in the Mississippi Delta, collected from an experimental field in Stoneville, MS was used in this study. Before the experiment started, field capacity for this soil was determined on soil dry weight basis. Three 19-liter pots were filled with $15 \mathrm{~kg}$ of soil and saturated with water setting them at room temperature. The pots were covered with plastic wrap and were left to drain for three days. Weights of each individual pot were recorded and the soil was then oven dried. Then soil water content at FC was calculated as the difference between the soil weight after drainage and soil weight after oven drying.

\subsection{Plant Growth Conditions and Soil Moisture Treatments}

Pots were filled with $15 \mathrm{~kg}$ of dry soil and each pot was placed on a scale (MyWeigh HD Series 150 Digital Scale) to monitor and record pot weight for water application. Corn seeds were planted in seedling starter inserts filled with potting soil, and when seedlings were ten days old one seedling was transplanted to each pot. The plants were grown at $30^{\circ} \mathrm{C} / 25^{\circ} \mathrm{C}$ day/night temperature in greenhouse with 14-h photoperiod (with supplemental lighting). After the seedlings were transplanted to pots, they were fertilized with half strength water soluble garden fertilizer (MiracleGro 18-18-21) during watering until they were three weeks old, and with full strength the- 
reafter at each watering until plants reached the silking stage. The plants were watered to $100 \%$ FC until soil moisture treatments were started. Pot weights were recorded daily and water was applied to maintain the desired level of soil moisture.

The first treatment started at the V14 growth stage. The pots assigned to this treatment were watered at 100\%, $75 \%$ and $50 \%$ FC, which continued until the plants reached physiological maturity. The other soil moisture treatments at the R1, R3 and R5 stages were also executed in the same manner, with irrigation treatments beginning at each growth stage and continuing through physiological maturity. Extra plants were grown under the same conditions and were harvested at the ten leaf stage, and at the beginning of each growth stage treatment. The weights of the harvested plants were used to account for the additional weight on the pots due to plant growth, and to adjust watering accordingly. Pot weight and amount of water added were recorded every morning.

\subsection{Crop Development and Yield Determination}

In this experiment the plants reached the V14 stage at 46 days after planting (DAP). The R1, R3 and R5 stages were reached at about 57, 71 and 82 DAP, respectively, and physiological maturity was reached at 98 DAP. Ears were harvested two weeks after physiological maturity and were air dried until seed moisture reached about 15\%. Data were collected on kernel weight per ear (yield), kernel number per ear, ear size (length and width) and total above ground biomass.

\subsection{Physiological Measurements}

A separate experiment was conducted for physiological measurements because leaf sampling could damage the plants in the main experiment and affect yield, and also the plants were too tall to reach for photosynthesis measurements at the V14 to R5 growth stages. Physiological measurements were conducted to monitor water deficit stress on the plants. The experiment was conducted using the same soil and greenhouse growing conditions as in the main experiment at the three soil moisture treatments (100\%, $75 \%$ and $50 \%$ FC). The experimental design was a randomized complete block with three soil moisture treatments in four replications. Soil moisture treatments were conducted when the plants were between the V10 to V12 (ten to twelve leaf) growth stages. Measurements were made on photosynthesis, chlorophyll and carotenoids content, and leaf relative water content.

Photosynthesis measurements were made on the youngest and fully expanded leaves between 10:00 am and 11:00 am on a sunny day. Photosynthesis was determined using a LI-6400XT portable photosynthesis system (Li-Cor Biosciences; Lincoln, NE) with a 6400-02(B) LED light source attached to the leaf chamber. Temperature in the leaf chamber was set at $30^{\circ} \mathrm{C}$. Carbon dioxide levels in the leaf chamber were controlled using $\mathrm{CO}_{2}$ cartridge at a fixed flow rate of $500 \mu \mathrm{mol} \cdot \mathrm{s}^{-1}$. Carbon dioxide concentration within the leaf chamber was fixed at $370 \mu \mathrm{mol} \cdot \mathrm{mol}^{-1}$.

Chlorophyll and carotenoids were determined on the same young and fully expanded leaves used for photosynthesis. Two 10-mm diameter leaf discs were taken from the middle part of the blade, placed in vials containing $2 \mathrm{ml}$ absolute ethanol and incubated for $24 \mathrm{~h}$ at room temperature $\left(25^{\circ} \mathrm{C}\right)$ in the dark. Chlorophyll a (Chl a) and chlorophyll $\mathrm{b}(\mathrm{Chl} \mathrm{b}$ ) were determined by measuring absorbance at 645 and $663 \mathrm{~nm}$ wavelengths on a spectrophotometer (Beckman Coulter DU 800 Spectrophotometer, Brea, CA) and computed following the method of Hendry and Price [19]. Then, total chlorophyll (Chl) and chlorophyll a/chlorophyll b ratio (Chl a/b) were calculated.

Relative water content was determined using six leaf discs with diameter of $17 \mathrm{~mm}$ taken from the youngest fully expanded leaves of each plant. The leaf samples were kept in vials in a cooler during sampling in the greenhouse, and as soon as they were brought to the lab fresh weight was determined for each sample, followed by flotation in deionized water for $8 \mathrm{hr}$. The turgid weight was then recorded, and the leaf tissue was subsequently oven-dried to a constant weight at about $70^{\circ} \mathrm{C}$ for 3 days. Relative water content (RWC) was then calculated as:

$$
\mathrm{RWC}(\%)=[(\mathrm{FW}-\mathrm{DW}) /(\mathrm{TW}-\mathrm{DW})] \times 100
$$

where, FW is fresh weight, DW is dry weight and TW is turgid weight of leaf samples.

\subsection{Seed Composition Analysis}

Corn kernels from each pot were analyzed for protein, oil, starch and fiber percentage using a near infrared (NIR) 
reflectance diode array feed analyzer (Petren, Springfield, IL) [20] [21]. Calibration equations were developed by Perten using Thermo Galactic Grams PLS IQ. The calibration curve has been regularly updated for unique samples according to AOAC methods [22] [23].

\subsection{Data Analysis}

Data on corn yield, yield components and seed composition were analyzed using the GLIMMIX procedure in SAS 9.3 (SAS Institute, Inc., Cary, N.C.) as a randomized complete block design with a $3 \times 4$ factorial, soil moisture treatments and growth stages as the experimental units. Analysis on data from the physiological measurements was conducted using the PROC ANOVA procedure in SAS.

\section{Results}

\subsection{Yield and Yield Components}

Soil moisture level had a highly significant effect on yield, but growth stage and growth stage by soil moisture interaction were not significant (Table 1). No significant differences in yield were observed between the $100 \%$ and the 75\% FC treatments at the R1 (silking), R3 (Milk) and R5 (dent) stages, but at the 50\% FC treatment yield was significantly lower than the $100 \%$ FC in all growth stages (Figure 1). At V14 growth stage, mean yield was reduced from $175 \mathrm{~g}$ at the $100 \%$ treatment to $145 \mathrm{~g}$ (17\% lower) and $132 \mathrm{~g}$ (24\% lower) at the $75 \%$ and 50\% treatments, respectively (Figure 1). At the R1, R3 and R5 growth stages the reduction in yield in the $75 \%$ FC treatment ranged only from $5 \%$ to $9 \%$, whereas it was $17 \%$ to $23 \%$ in the $50 \%$ FC treatment compared with the $100 \%$.

Soil moisture level and growth stage had highly significant effect on average kernel number per ear (Table 1). Kernel number was significantly higher in the $100 \%$ and $75 \%$ FC treatments with significantly higher values at the R3 and R5 growth stages (Table 2(a) and Table 2(b)). Ear weight and ear width were highly significantly affected by soil moisture level, but not by growth stage. Ear weight was significantly higher at the $100 \% \mathrm{FC}$ and was the lowest at the 50\% FC treatment (Table 2(a)). Ear width was significantly higher at the $100 \%$ and the $75 \%$ FC treatments than at the 50\% FC treatment. Shoot biomass was highly significantly affected by growth stage and by the interaction of growth stage and soil moisture (Table 2(c)). However, the variation in shoot biomass did not seem to be related to any specific soil moisture treatment or growth stage.

It was observed that, after tasseling, the plants still grew taller to various degrees, which is not the case in field grown corn plants. This could be due to greenhouse growing conditions and could have been the cause for the random variation in the amount of dry matter accumulated in the plants.

\subsection{Water Use}

Both soil moisture and growth stage had significant effects on water use. Average water use per plant for the 100\% FC treatment was about 53 liters (Table 3). Water savings in the 75\% FC and 50\% FC treatments were

Table 1. Analysis of variance (P values) for kernel weight (yield) kernel number per ear, ear weight, ear width, shoot biomass, water use efficiency (WUE, kernel weight per liter of water), WUE (shoot biomass per liter of water), and seed composition (protein, oil, fiber and starch).

\begin{tabular}{|c|c|c|c|c|c|c|c|}
\hline Effect & DF & Kernel weight & Kernel number & Ear weight & Ear width & Ear length & Shoot biomass \\
\hline Soil moisture & 2 & $0.0003^{* *}$ & $0.0193^{*}$ & $0.0001^{* *}$ & $0.0015^{* *}$ & 0.2285 & 0.8235 \\
\hline Growth stage & 3 & 0.7072 & $0.0386^{*}$ & 0.8896 & 0.8112 & 0.0781 & $0.0202^{*}$ \\
\hline $\begin{array}{c}\text { Growth stage } \times \\
\text { soil moisture }\end{array}$ & 6 & 0.8132 & 0.1118 & 0.8622 & 0.8475 & 0.3133 & $0.0445^{*}$ \\
\hline Effect & & WUE (kernel wt $\cdot \mathrm{L}^{-1}$ ) & WUE (biom $\cdot \mathrm{L}^{-1}$ ) & Protein & Oil & Fiber & Starch \\
\hline Soil moisture & 2 & 0.1498 & $0.0004^{* *}$ & $0.0044^{* *}$ & 0.5259 & 0.5071 & 0.4014 \\
\hline Growth stage & 3 & 0.5940 & $0.0002^{* *}$ & $0.0509^{*}$ & 0.3665 & 0.0951 & 0.2539 \\
\hline $\begin{array}{l}\text { Growth stage } \times \\
\text { soil moisture }\end{array}$ & 6 & 0.8487 & $0.0166^{*}$ & 0.0814 & 0.1437 & 0.7395 & 0.1153 \\
\hline
\end{tabular}

${ }^{*} \mathrm{P} \leq 0.05$ and ${ }^{* *} \mathrm{P} \leq 0.01$. 


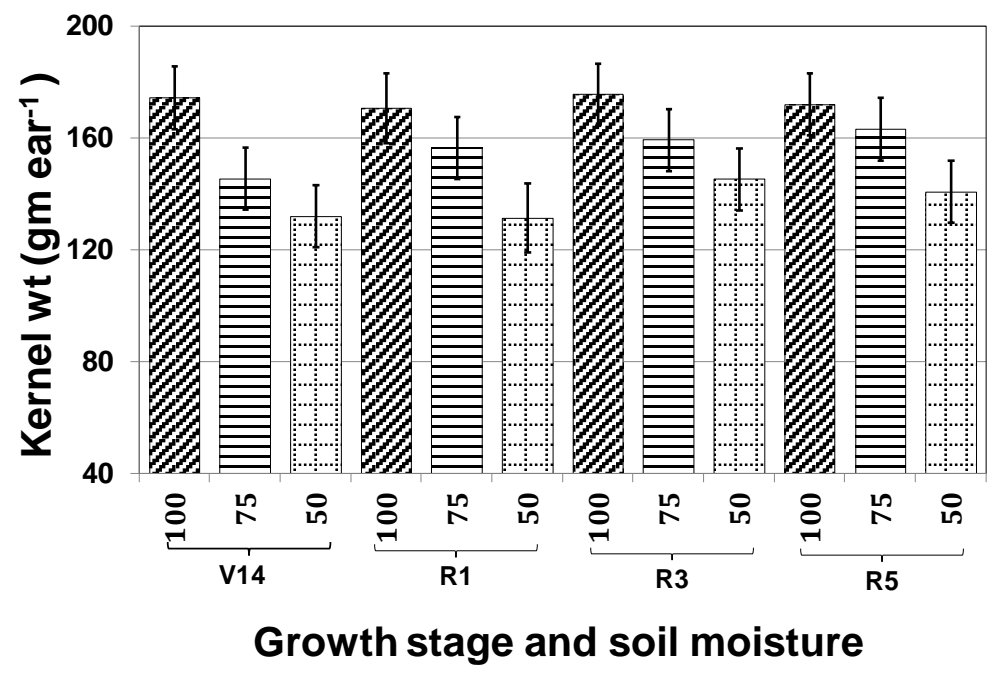

Figure 1. Corn kernel weight per ear in grams as influenced by soil moisture treatments $(100=100 \%$ of field capacity (FC), $75=75 \%$ FC, $50=50 \%$ FC) at different growth stages (V14 = fourteen leaf stage, R1 = silk stage, R3 = milk stage and R5 = dent stage).

Table 2. (a) Kernel number per ear, ear weight (gm), ear width $(\mathrm{cm})$ and kernel protein content (\%) averaged over soil moisture treatment; (b) Kernel number per ear, shoot biomass and kernel protein content (\%) averaged over growth stage; and (c) Average shoot biomass and protein content at the different soil moisture and growth stage combinations.

(a)

\begin{tabular}{cccc}
\hline Soil moisture (\% FC) & Kernel number & Ear weight (gm) & Ear width (cm) \\
\hline 100 & $531 \mathrm{a}$ & $232 \mathrm{a}$ & $5.1 \mathrm{a}$ \\
75 & $532 \mathrm{a}$ & $214 \mathrm{~b}$ & $4.9 \mathrm{a}$ \\
50 & $460 \mathrm{~b}$ & $187 \mathrm{c}$ & $4.6 \mathrm{~b}$ \\
\hline
\end{tabular}

(b)

\begin{tabular}{ccc}
\hline Growth stage & Kernel number & Shoot biomass (gm) \\
\hline V14 & $453 \mathrm{~b}$ & $334 \mathrm{a}$ \\
R1 & $514 \mathrm{ab}$ & $337 \mathrm{a}$ \\
R3 & $519 \mathrm{a}$ & $317 \mathrm{ab}$ \\
R5 & $545 \mathrm{a}$ & $299 \mathrm{~b}$ \\
\hline
\end{tabular}

(c)

\begin{tabular}{|c|c|c|c|}
\hline Growth stage & Soil moisture (\% FC) & Shoot biomass (gm) & Protein (\%) \\
\hline V14 & 100 & 313 bcd & 10.08 e \\
\hline V14 & 75 & 320 bcd & $10.65 \mathrm{~b}$ \\
\hline V14 & 50 & 369 a & $11.00 \mathrm{a}$ \\
\hline $\mathrm{R} 1$ & 100 & $357 \mathrm{ab}$ & $10.03 \mathrm{e}$ \\
\hline $\mathrm{R} 1$ & 75 & $329 a b c$ & 10.53 bc \\
\hline $\mathrm{R} 1$ & 50 & $324 a b c$ & $11.1 \mathrm{a}$ \\
\hline R3 & 100 & $296 \mathrm{~cd}$ & 10.23 de \\
\hline R3 & 75 & 326 abc & 10.15 e \\
\hline R3 & 50 & 329 abc & 10.03 e \\
\hline R5 & 100 & $308 \mathrm{~cd}$ & $10.11 \mathrm{e}$ \\
\hline R5 & 75 & $309 \mathrm{~cd}$ & 10.55 bc \\
\hline R5 & 50 & $279 \mathrm{~d}$ & $10.43 \mathrm{~cd}$ \\
\hline
\end{tabular}

Means with different letters in columns are significantly different $(\mathrm{P}<0.05)$. 
Table 3. Average yield reduction in percentage at the $75 \%$ and $50 \%$ field capacity soil moisture treatments for all growth stages, average water used for each treatment and water saved in liters and in percentage relative to the $100 \%$ field capacity treatment.

\begin{tabular}{cccccc}
\hline \multirow{2}{*}{ Growth stage } & \multicolumn{2}{c}{ Water use } & \multicolumn{2}{c}{ Yield } \\
\cline { 2 - 6 } & Total water (L) & Water saved (L) & Water saved (\%) & Yield (grams) & Yield reduction (\%) \\
\hline V14-100 & $52.5 \mathrm{a}$ & 0 & 0 & $174.5 \mathrm{a}$ & 0 \\
V14-75 & $44.7 \mathrm{~cd}$ & 7.8 & 14.9 & $145.4 \mathrm{~b}$ & 16.7 \\
V14-50 & $41.0 \mathrm{~d}$ & 11.5 & 21.9 & $132.1 \mathrm{~b}$ & 0 \\
R1-100 & $52.4 \mathrm{a}$ & 0 & 0 & $170.7 \mathrm{a}$ & 8.3 \\
R1-75 & $47.1 \mathrm{bc}$ & 5.3 & 10.1 & $156.2 \mathrm{a}$ & 23.0 \\
R1-50 & $43.7 \mathrm{~cd}$ & 9.7 & 16.6 & $131.4 \mathrm{~b}$ & 0 \\
R3-100 & $53.0 \mathrm{a}$ & 0 & 0 & $175.2 \mathrm{a}$ & 9.1 \\
R3-75 & $50.1 \mathrm{ab}$ & 2.9 & 5.5 & $159.3 \mathrm{ab}$ & 17.1 \\
R3-50 & $45.9 \mathrm{c}$ & 7.1 & 13.4 & $145.2 \mathrm{~b}$ & 0 \\
R5-100 & $55.5 \mathrm{a}$ & 0 & 0 & $172.1 \mathrm{a}$ & $163.2 \mathrm{a}$ \\
R5-75 & $50.5 \mathrm{ab}$ & 3.1 & 5.8 & $140.7 \mathrm{~b}$ & 5.2 \\
R5-50 & $49.8 \mathrm{ab}$ & 3.8 & 7.1 & & 18.2 \\
\hline
\end{tabular}

Means with different letters in columns are significantly different $(\mathrm{P}<0.05)$.

significantly higher at the V14 and R1 growth stages compared with water used in the $100 \%$ FC treatment. The $75 \%$ FC treatment saved about 8 liters (15\%) at the V14 stage, but yield was significantly lower at this growth stage compared to the $100 \%$ FC treatment (Table 3$)$. At the R1 growth stage, about 5 liters (10\%) of water was saved at the $75 \%$ FC treatment without a significant reduction in yield relative to the $100 \%$ FC treatment. At the R3 and R5 stages, 3 liters (6\%) and 3 liters (6\%) were saved, respectively, but this amount of water was not significantly lower than the amount used for the $100 \%$ FC. In the $50 \%$ FC treatment, water savings were significantly greater than in the $100 \%$ FC treatment at the V14, R1 and R3 growth stages, with average values of about 12 liters (22\%), 10 liters (17\%) and 7 liters (13\%), respectively (Table 3). However, all these water savings at the $50 \%$ FC treatments were gained with significant yield loss.

Kernel weight or yield per liter of water (water use efficiency) was not significantly different among the different soil moisture treatments at the different growth stages as shown in Figure 2(a). However, water use efficiency based on dry shoot biomass was significantly different among the soil moisture treatments within each growth stage (Figure 2(b)). Values for the 50\% FC treatments were significantly higher than those of the 100\% and the 75\% treatments at the V14, R1 and R3 stages with the highest value at the V14 stage.

\subsection{Physiological Responses}

Physiological measurements were conducted between the V10 and V12 growth stages to determine the stress level on the plants under the reduced soil moisture treatments. Gas exchange properties (photosynthesis, stomatal conductance, internal $\mathrm{CO}_{2}$ concentration and transpiration) showed differences at the $100 \% \mathrm{FC}, 75 \% \mathrm{FC}$ and $50 \%$ FC soil moisture treatments. Photosynthesis or assimilation rate (A) was significantly reduced at the $75 \%$ and 50\% FC treatments (Table 4). At the $100 \%$ FC treatment A was about $25 \mu \mathrm{mol} \cdot \mathrm{m}^{-2} \cdot \mathrm{s}^{-1}$, and at the $75 \%$ treatment it was reduced to about $23 \mu \mathrm{mol} \cdot \mathrm{m}^{-2} \cdot \mathrm{s}^{-1}$, but at the $50 \% \mathrm{FC}$ treatment reduction was more than $50 \%$ $\left(11.2 \mu \mathrm{mol} \cdot \mathrm{m}^{-2} \cdot \mathrm{s}^{-1}\right)$. Stomatal conductance $\left(\mathrm{g}_{\mathrm{s}}\right)$ and transpiration (E) were not significantly different at the $100 \%$ and $75 \%$ FC treatments, but were significantly lower at the $50 \%$ FC. Internal $\mathrm{CO}_{2}$ concentration $\left(\mathrm{C}_{\mathrm{i}}\right)$ was significantly higher at the 50\% FC treatment (Table 4). Photosynthetic pigments (Chlorophyll and Chlorophyll a/Chlorophyll b ratio) showed significant difference in the three soil moisture treatments. Chlorophyll content (Chl) showed a similar response pattern as A. There was a significant reduction in $\mathrm{Chl}$ at $75 \% \mathrm{FC}$ and $50 \%$ 


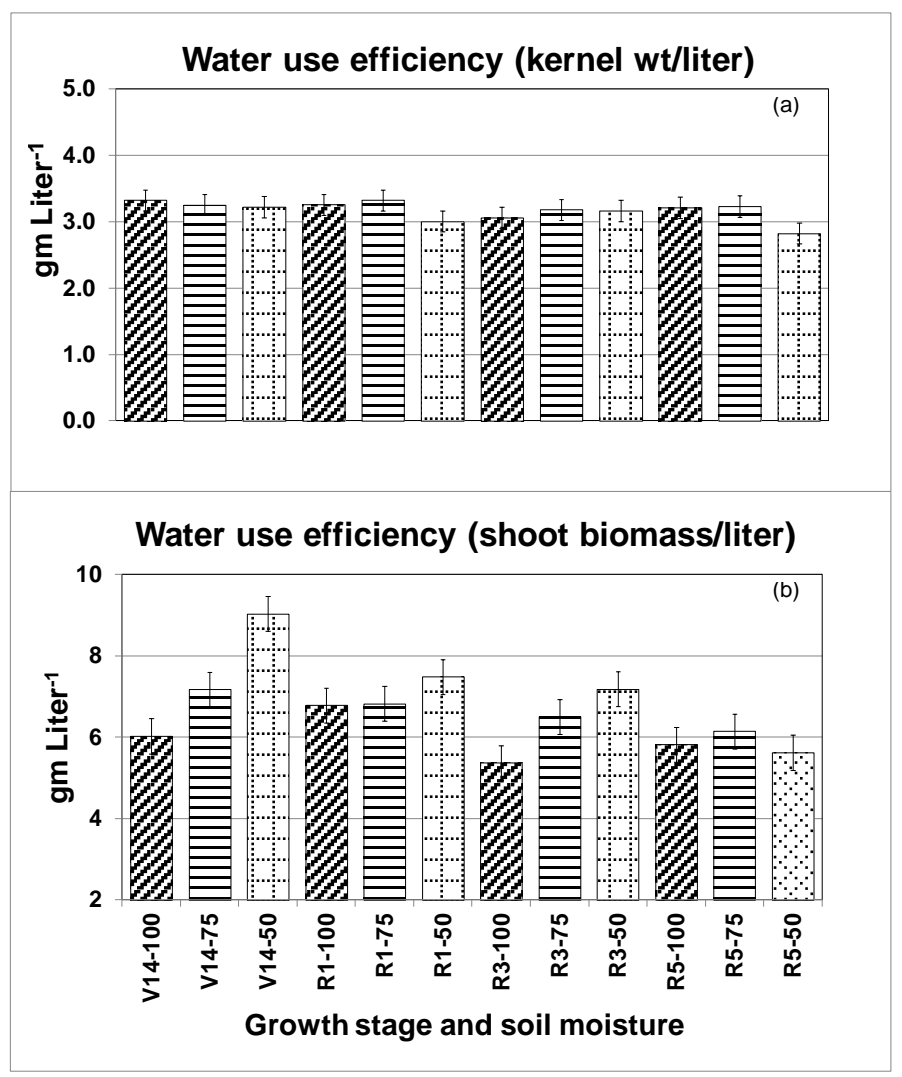

Figure 2. Water use efficiency based on (a) Kernel weight in grams per liter of water and (b) Dry shoot biomass in grams per liter of water, at the $100 \%, 75 \%$ and $50 \%$ field capacity (FC) treatments at the V14, R1, R3 and R5 growth stages.

Table 4. Photosynthesis (A), stomatal conductance $\left(\mathrm{g}_{\mathrm{s}}\right)$, internal $\mathrm{CO}_{2}$ concentration $\left(\mathrm{C}_{\mathrm{i}}\right)$, transpiration (E), relative water content (RWC), chlorophyll (Chl) and chlorophyll a/chlorophyll b ratio (Chl a/b) at three soil moisture treatments (100\%, $75 \%$ and $50 \%$ of field capacity of silt loam soil) conducted on young and fully expanded leaves of greenhouse grown corn plants at 10 to 12 leaf (V10 to V12) growth stage.

\begin{tabular}{|c|c|c|c|c|}
\hline Soil moisture (\% FC) & $A\left(\mu \mathrm{mol} \cdot \mathrm{m}^{-2} \cdot \mathrm{s}^{-1}\right)$ & $\mathrm{g}_{\mathrm{s}}\left(\mathrm{mol} \cdot \mathrm{m}^{-2} \cdot \mathrm{s}^{-1}\right)$ & $\mathrm{C}_{\mathrm{i}}\left(\mu \mathrm{mol} \cdot \mathrm{mol}^{-1}\right)$ & $\mathrm{E}\left(\mathrm{mol} \cdot \mathrm{m}^{-2} \cdot \mathrm{s}^{-1}\right)$ \\
\hline 100 & 24.7 a & $0.47 \mathrm{a}$ & $192 \mathrm{~b}$ & $5.2 \mathrm{a}$ \\
\hline 75 & $22.9 \mathrm{~b}$ & $0.44 \mathrm{a}$ & $208 \mathrm{~b}$ & $5.1 \mathrm{a}$ \\
\hline 50 & $11.2 \mathrm{c}$ & $0.20 \mathrm{~b}$ & $284 \mathrm{a}$ & $2.7 \mathrm{~b}$ \\
\hline Soil moisture (\% FC) & RWC (\%) & Chl $\left(\mu \mathrm{mol} \cdot \mathrm{cm}^{-2}\right)$ & Chl a/b & \\
\hline 100 & $94.4 \mathrm{a}$ & $33.1 \mathrm{a}$ & $2.59 \mathrm{~b}$ & \\
\hline 75 & $92.8 \mathrm{a}$ & $31.4 \mathrm{~b}$ & $2.76 \mathrm{ab}$ & \\
\hline 50 & $83.8 \mathrm{~b}$ & $29.4 \mathrm{c}$ & $3.05 \mathrm{a}$ & \\
\hline
\end{tabular}

Means with different letters in columns are significantly different $(\mathrm{P}<0.05)$.

FC treatments, with values of $33.1 \mu \mathrm{mol} \cdot \mathrm{cm}^{-2}, 31.4 \mu \mathrm{mol} \cdot \mathrm{cm}^{-2}$ and $29.4 \mu \mathrm{mol} \cdot \mathrm{cm}^{-2}$ at $100 \mathrm{FC}, 75 \% \mathrm{FC}$ and $50 \%$ FC, respectively (Table 4). Chlorophyll a/Chlorophyll b ratio (Chl a/b) showed a significantly higher value at the $50 \%$ FC, but was similar at the $100 \%$ and $75 \%$ FC. Leaf relative water content (RWC) was reduced at $75 \%$ FC, but was not significantly different from the 100\% FC treatment $(94.4 \%$ and $92.8 \%$ for the $100 \%$ FC and $75 \%$ FC treatments, respectively), but there was a significant reduction at $50 \%$ FC treatment, to a value of 
$83.8 \%$.

\subsection{Seed Composition}

Soil moisture treatments and growth stages had significant effect on percent kernel protein content (Table 1, Table 2(c)). No significant changes were observed in oil, fiber and starch under the different soil moisture treatments and growth stages (Table 1). Percent kernel protein content was significantly higher in the 50\% FC treatments at the V14 and R1 growth stages followed by the 75\% FC treatment in the V14 and R1 growth stages (Table 2(c)). All the 100\% FC treatments had significantly lower kernel protein content. At the R3 and R5 growth stages, the $50 \%$ and $75 \%$ FC treatments had intermediate to low protein content indicating that reduced soil moisture at the later stages of the corn growth had less effect on kernel protein content.

\section{Discussion}

This study showed that reducing soil moisture from 100\% FC to $75 \%$ FC of a silt loam soil starting at the R1 growth stage in corn resulted in some reduction in yield, but yield was not significantly lower from that of the $100 \%$ FC treatment. This reduction in soil moisture starting at the R1 stage saved a significant amount of water with little compromise in yield. Maximum yield reduction due to moisture deficit stress in corn occurs at R1 or silking stage due to unsuccessful fertilization of the ovules during pollination [24]-[27]. However, in this study reducing soil moisture to $75 \%$ FC of a silt loam soil did not affect yield significantly. This could be partially explained by the water holding capacity of the soil. The amount of plant available water at $75 \%$ FC varies with soil textural class. Silt loam soils hold the largest amount of plant available water with 1.7 - 2.1 millimeters of water per centimeter of soil depth, whereas clay and sandy soils have 1.0 - 1.25 and 0.6 - 0.8 millimeters of water per centimeter, respectively [16] [17]. This means there is more soil water available to plants at $75 \%$ FC in the silt loam soil than the other soil textural classes. Therefore, the $75 \%$ FC treatment at the R1 stage may have retained sufficient moisture to maintain fertilization and development of kernels and produce yield comparable or close to that of the $100 \%$ FC treatment. Moreover, in the present study, the soil moisture treatments at the different growth stages were continued until maturity rather than a brief stress treatment only during a specific growth stage, as in other studies [7] [26].

The 50\% FC treatment had higher water savings than the 75\% FC treatment, but these water savings costed significant yield reductions. The $50 \%$ FC treatment might have had significant moisture deficit stress on the plants starting at the V14 growth stage, as observed from the delay in tassel and silk emergence, and this has been reported in other studies in corn plants under moisture deficit stress [7] [8] [24]. Out of all the vegetative growth stages, the period V14 to V15 growth stage is the most critical period for seed yield determination [6] [28] [29]. The number of ovules that develop silks, which in turn would determine the number of kernels per row, is determined at this stage, thus moisture deficiency at this stage may seriously reduce the number of kernels that develop [6] [27] [28]. In the present study, significant reduction in yield at 50\% FC at the V14 stage could have been brought about by reduction in the number of ovules that develop silks. Moisture deficit stress that continues after pollination into the early stages of kernel development can abort developing kernels [6] [7]. In this study this could have occurred in the $50 \%$ FC treatments at the R1 growth stage resulting in significant yield reduction, and to some extent in the 75\% FC treatment. At the R3 and the R5 growth stages, the significant yield reductions at the $50 \%$ FC treatments could have been due to reduction in kernel weight because of insufficient supply of carbohydrates to get the kernels to their final size and weight [30] [31]. The significantly lower ear weight and ear width in the $50 \%$ FC treatment at these growth stages could also have resulted due to the smaller kernel sizes.

Reducing soil moisture to 75\% FC significantly reduced A and Chl at the vegetative growth stages, even though reduction in RWC was not significant. This may suggest that these physiological parameters were affected before a significant reduction in leaf water content occurred, or that there might have been additional factors that contribute to their reduction. Decrease in $\mathrm{A}$ is a result of stomatal limitations (low stomatal conductance which limits availability of $\mathrm{CO}_{2}$ for $\mathrm{A}$ ) and non-stomatal limitations (reduction in biochemical capacity for carbon assimilation) [9] [14] [15]. In this study, in the 50\% FC treatment, the highly significant reduction in A could have been due to both stomatal and biochemical limitations as indicated by the significantly lower $\mathrm{g}_{\mathrm{s}}$ and higher $\mathrm{C}_{\mathrm{i}}$ values. However, in the 75\% FC treatment stomatal limitation did not seem to have much effect on reduction of A as $g_{s}$ values were similar between the $100 \%$ FC and the $75 \%$ FC treatments and there was a 
higher $\mathrm{C}_{\mathrm{i}}$ in the $75 \% \mathrm{FC}$, which could be a sign of reduction in biochemical processes in the photosynthetic apparatus. Chlorophyll a/b ratio is elevated when plants are stressed and has been reported to be a good indicator of the stress level on a plant [32] [33]. The $\mathrm{Chl}$ a/b ratio was significantly higher in the $50 \%$ FC treatment showing that the plants under this treatment were the most stressed as indicated by all the other physiological parameters, but the $75 \%$ FC treatment had intermediate values between the $100 \%$ FC and the $50 \%$ FC treatments, suggesting that there were some signs of stress on the plants at this level of soil moisture. Results from these physiological parameters suggest that soil moisture deficit stress on the plants may have started at the $75 \%$ FC treatment.

Limited water availability can significantly impair A, reducing the amount of assimilate available for grain development [9] [31]. Kernel growth and development in corn is highly dependent on assimilate supply from concurrent photosynthesis, supplemented with remobilized stem carbohydrate reserves during grain fill [11] [12]. Although the A measurements in this study were conducted at the vegetative growth stage, we could perhaps relate the reduction in A to the reduction in grain yield at the different soil moisture treatments and growth stages. The significantly lower yields at the 50\% FC treatment in all growth stages might have resulted primarily due to significantly lower A at this soil moisture treatment. Likewise, in the $75 \%$ FC treatment, the slight reduction in yield in all the growth stages, compared to the $100 \%$ FC, might have been due to lower A.

Kernel protein content was altered with reduction in soil moisture from $100 \%$ FC to $75 \%$ and $50 \%$ in a silt loam soil in this study, but the degree of this alteration depended on the growth stage of the plants, with significant effect at the earlier growth stages and less or no effect at the latter growth stages. The non-significant differences in kernel oil and starch contents among treatments may reflect that kernel oil and starch were less sensitive to the soil moisture treatments compared with protein content. However, in a previous study conducted under irrigated and non-irrigated field conditions, starch content was significantly lower and protein content was significantly higher under non-irrigated conditions in commercial corn hybrids [34]. The absence of effect of soil moisture treatments in starch content in this study could perhaps be due to the fact that the reduction in soil moisture to 50\% FC in silt loam soil did not reach the threshold amount that could result in changes in starch content.

\section{Summary}

In this study, an investigation to determine the reproductive and grain fill stages in corn at which water could be reduced without affecting grain yield showed that, in a silt loam soil, reducing soil moisture to $75 \%$ of the field capacity starting at the R1 stage did not reduce yield significantly and saved a significant amount of water. If further tests show that the savings in water could bring significant reduction in energy cost for irrigation, it may be profitable to reduce soil moisture to $75 \%$ FC in a silt loam soil. Physiological investigations suggested that corn plants showed some signs of moisture deficit stress at the $75 \%$ FC treatment. This study was conducted under greenhouse conditions and might not represent the field environment. Therefore, it needs to be tested under the humid and hot Mississippi Delta environmental conditions.

\section{Acknowledgements}

The authors wish to thank Jason Corbitt, Jonnie Baggard, Keysha Hamilton and Sandra Mosley for technical assistance. Mention of trade names or commercial products in this publication is solely for the purpose of providing specific information and does not imply recommendation or endorsement by the US Department of Agriculture.

\section{References}

[1] Fereres, E. and Soriano, M.A. (2007) Deficit Irrigation for Reducing Agricultural Water Use. Journal of Experimental Botany, 58, 147-159. http://dx.doi.org/10.1093/jxb/erl165

[2] Stewart, W.L., Fulton, A.E., Krueger, W.H., Lampinen, B.D. and Shakel, K.A. (2011) Regulated Deficit Irrigation Water Use of Almonds without Affecting Yield. California Agriculture, 65, 90-95. http://dx.doi.org/10.3733/ca.v065n02p90

[3] Wax, C.L., Pote, J.W. and Merrell, T.L. (2008) Climatological and Cultural Influences on Annual Groundwater Decline in the Mississippi Shallow Alluvial Aquifer. The 38th Annual Mississippi Water Resources Research Conference, Jackson. 
[4] Weiss, M. (2014) Assessment of Trends in Groundwater Levels across the United States. Columbia Water Center, Earth Institute, Columbia University, New York.

http://water.columbia.edu/2014/03/17/assessment-of-trends-in-groundwater-levels-across-the-united-states/

[5] Farahani, H. and Smith, W.B. (2014) Irrigation-Making the Case for Irrigated Corn. Clemson University Cooperative Extension. http://www.clemson.edu/extension/rowcrops/corn/guide/irrigation.html

[6] Nielsen, R.L. (2013) Effects of Stress during Grain Filling in Corn. Corny News Network, Purdue University, West Lafayette. http://www.agry.purdue.edu/ext/corn/news/timeless/grainfillstress.html

[7] Setter, T.L., Flannigan, B.A. and Melkonian, J. (2001) Loss of Kernel Set Due to Water Deficit and Shade in Maize: Carbohydrate Supplies, Abscisic Acid, and Cytokinins. Crop Science, 41, 1530-1540. http://dx.doi.org/10.2135/cropsci2001.4151530x

[8] Blum, A. (1996) Crop Response to Drought and the Interpretation of Adaptation. Plant Growth Regulation, 20, 135148. http://dx.doi.org/10.1007/BF00024010

[9] Chaves, M.M., Pereira, J.S., Maroco, J., Rodrigues, M.L., Ricardo, C.P.P., Osorio, M.L., Carvalho, I., Faria, T. and Pinheiro, C. (2002) How Plants Cope with Stress in the Field. Photosynthesis and Growth. Annals of Botany, 89, 907-916. http://dx.doi.org/10.1093/aob/mcf105

[10] Subrahmanyam, D., Subash, N., Haris, A. and Sikka, A.K. (2006) Influence of Water Stress on Leaf Photosynthetic Characteristics in Wheat Cultivars Differing in Their Susceptibility to Drought. Photosynthetica, 44, 125-129. http://dx.doi.org/10.1007/s11099-005-0167-y

[11] Schussler, J.R. and Westgate, M.E. (1991) Maize Kernel Set at Low Water Potential: II. Sensitivity to Reduced Assimilate Supply at Pollination. Crop Science, 31, 1196-1203.

[12] Andrade, F.H., Echarte, L., Rizzalli, R., Maggiora, A.D. and Casanovas, M. (2002) Kernel Number Prediction in Maize under Nitrogen and Water Stress. Crop Science, 42, 1173-1179. http://dx.doi.org/10.2135/cropsci2002.1173

[13] Prasad, P.V.V., Pisipati, S.R., Momčilović, I. and Ristic, Z. (2011) Independent and Combined Effects of High Temperature and Drought Stress during Grain Filling on Plant Yield and Chloroplast EF-Tu Expression in Spring Wheat. Journal of Agronomy and Crop Science, 197, 430-441. http://dx.doi.org/10.1111/j.1439-037X.2011.00477.x

[14] Wise, R.R., Ortiz-Lopez, A. and Ort, D.R. (1992) Spatial Distribution of Photosynthesis during Drought in FieldGrown and Acclimated and Nonacclimated Growth Chamber-Grown Cotton. Plant Physiology, 100, 26-32. http://dx.doi.org/10.1104/pp.100.1.26

[15] Farooq, M., Wahid, A., Kobayashi, N., Fujita, D. and Basra, S.M.A. (2009) Plant Drought Stress: Effects, Mechanisms and Management. Agronomy for Sustainable Development, 29, 185-212. http://dx.doi.org/10.1051/agro:2008021

[16] Ball, J. (2001) Soil and Water Relationships. The Samuel Roberts Noble Foundation. Ag News and Views. http://www.noble.org/ag/soils/soilwaterrelationships/

[17] USDA Natural Resources Conservation Service (2008) Soil Quality Indicators. http://www.nrcs.usda.gov/Internet/FSE_DOCUMENTS/nrcs142p2_053288.pdf

[18] Plaster, E.J. (2013) Soil Science and Management. 6th Edition, Delmar Cengage Learning, Clifton Park, 165-167.

[19] Hendry, G.A.F. and Price, A.H. (1993) Stress Indicators: Chlorophylls and Carotenoids. In: Hendry, G.A.F. and Grime, J.P., Eds., Methods in Comparative Plant Ecology, Chapman \& Hall, London, 148-152.

[20] Bellaloui, N. (2011) Effect of Water Stress and Foliar Boron Application on Seed Protein, Oil, Fatty Acids, and Nitrogen Metabolism in Soybean. American Journal of Plant Sciences, 2, 692-701. http://dx.doi.org/10.4236/ajps.2011.25084

[21] Reddy, K.N., Bellaloui, N. and Zablotowicz, R.M. (2010) Glyphosate Effect on Shikimate, Nitrate Reductase Activity, Yield and Seed Composition in Corn. Journal of Agricultural and Food Chemistry, 58, 3646-3650. http://dx.doi.org/10.1021/jf904121y

[22] The Association of Official Analytical Chemists (1990) Method 988.05. In: Helrich, K., Ed., Official Methods of Analysis, 15th Edition, The Association of Official Analytical Chemists, Inc., Arlington.

[23] The Association of Official Analytical Chemists (1990) Method 920.39. In: Helrich, K., Ed., Official Methods of Analysis, 15th Edition, The Association of Official Analytical Chemists, Inc., Arlington.

[24] Claassen, M.M. and Shaw, R. H (1970) Water Deficit Effects on Corn. I. Grain Components. Agronomy Journal, 62, 652-655. http://dx.doi.org/10.2134/agronj1970.00021962006200050032x

[25] Grant, R.F., Jackson, B.S., Kiniry, J.R. and Arkin, G.F. (1989) Water Deficit Timing Effects on Yield Components in Maize. Agronomy Journal, 81, 61-65. http://dx.doi.org/10.2134/agronj1989.00021962008100010011x

[26] Eck, H.V. (1986) Effects of Water Deficits on Yield, Yield Components and Water Use Efficiency of Irrigated Corn. Agronomy Journal, 78, 1035-1040. http://dx.doi.org/10.2134/agronj1986.00021962007800060020x

[27] Zinselmeier, C., Jeong, B.R. and Boyer, J.S. (1999) Starch and the Control of Kernel Number in Maize at Low Water 
Potentials. Plant Physiology, 121, 25-36. http://dx.doi.org/10.1104/pp.121.1.25

[28] Smith, H.R. and Conger, C. (2011) Corn Production Notes. Row Crops Newsletter, Mississippi State University Extension Service.

[29] Ransom, J. (2013) Corn Growth and Management. North Dakota State University Extension Service, A1173. http://www.ag.ndsu.edu/pubs/plantsci/crops/a1173.pdf

[30] Yang, J.C. and Zhang, J.H. (2006) Grain Filling of Cereals under Soil Drying. New Phytologist, 169, 223-236. http://dx.doi.org/10.1111/j.1469-8137.2005.01597.x

[31] Barnabas, B., Jager, K. and Feher, A. (2008) The Effect of Drought and Heat Stress on Reproductive Processes in Cereals. Plant, Cell and Environment, 31, 11-38.

[32] Alberte, S.R. and Thornber, J.P. (1977) Water Stress Effects on the Content and Organization of Chlorophyll in Mesophyll and Bundle Sheath Chloroplasts of Maize. Plant Physiology, 59, 351-353. http://dx.doi.org/10.1104/pp.59.3.351

[33] Camejo, D., Rodríguez, P., Morales, M.A., Dell’Amico, J.M., Torrecillas, A. and Alarcon, J.J. (2005) High Temperature Effects on Photosynthetic Activity of Two Tomato Cultivars with Different Heat Susceptibility. Journal of Plant Physiology, 162, 281-289. http://dx.doi.org/10.1016/j.jplph.2004.07.014

[34] Kebede, H., Abbas, H.K., Fisher, D.K. and Bellaloui, N. (2012) Relationship between Aflatoxin Contamination and Physiological Responses of Corn Plants under Drought and Heat Stress. Toxins, 4, 1385-1403. http://dx.doi.org/10.3390/toxins4111385 
Scientific Research Publishing (SCIRP) is one of the largest Open Access journal publishers. It is currently publishing more than 200 open access, online, peer-reviewed journals covering a wide range of academic disciplines. SCIRP serves the worldwide academic communities and contributes to the progress and application of science with its publication.

Other selected journals from SCIRP are listed as below. Submit your manuscript to us via either submit@scirp.org or Online Submission Portal.
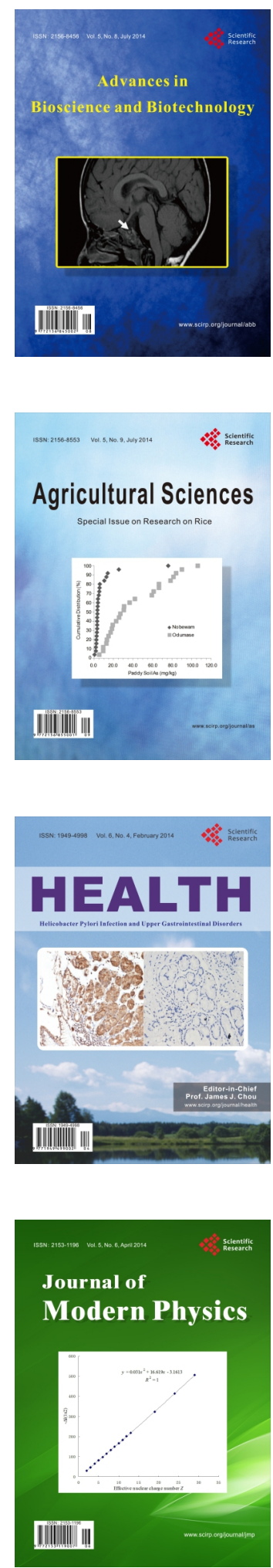
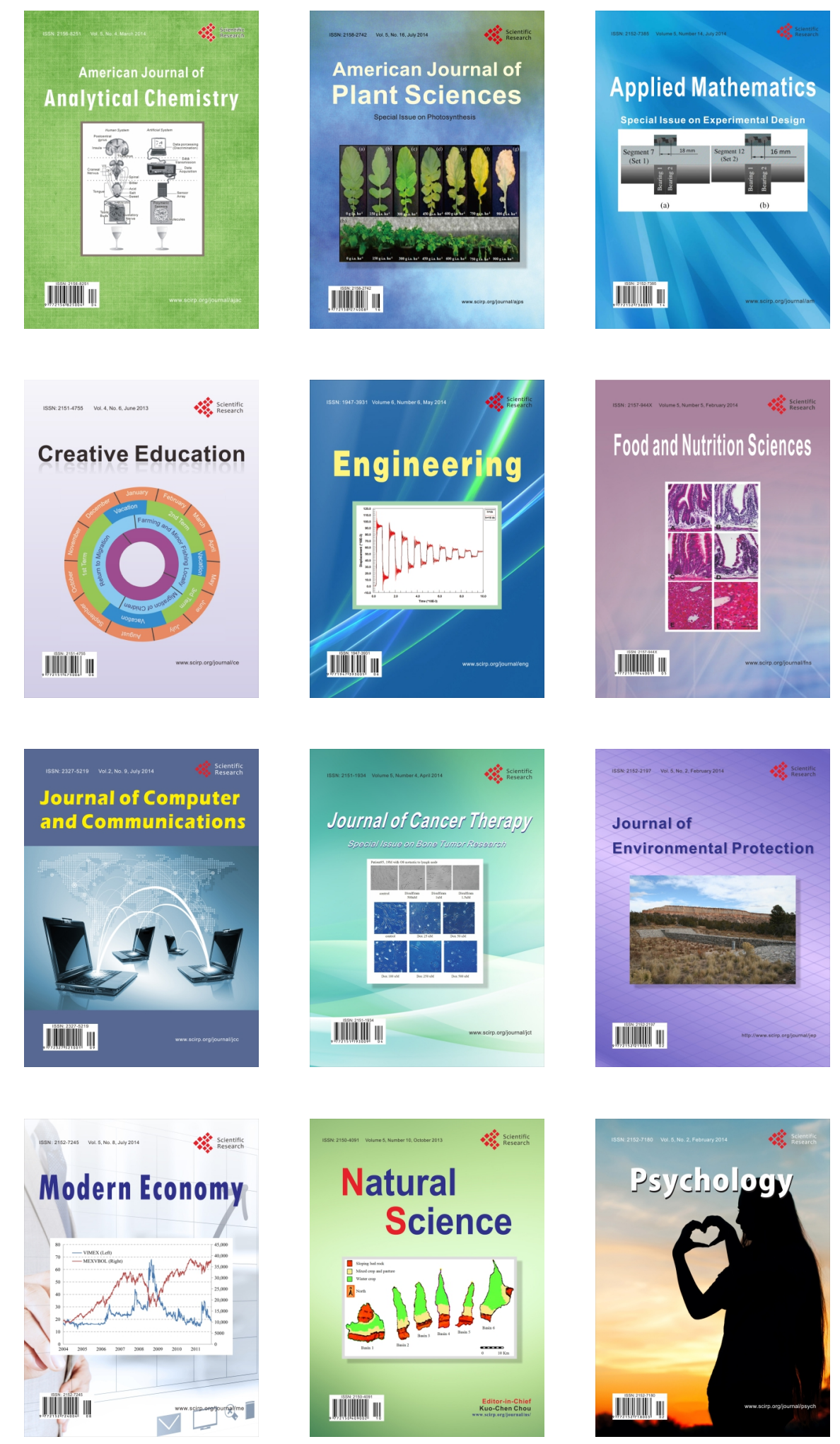